INDONESIAN HEALTH ISSUE

\title{
Analisis Kecemasan Ibu Hamil Menghadapi Persalinan Pada Masa Pandemi Covid-19
}

\author{
Astaria Br Ginting ${ }^{1}$, Elida Berta Tarigan ${ }^{2}$, Edi Subroto ${ }^{3}$, Anna Waris Nainggolan $^{4}$ \\ ${ }^{1-4}$ STIKes Mitra Husada Medan
}

Email korespondensi: feliciajovitasembiring@gmail.com

No HP: 085296345890

\begin{tabular}{l}
\hline ARTICLE INFO \\
Received : \\
12 Januari 2022 \\
Accepted: \\
14 Februari 2022 \\
Published : \\
16 Februari 2022 \\
\hline
\end{tabular}

Kata Kunci:

Kecemasan;

Persalinan; Pandemi

Covid 19; Ibu Hamil

\section{Keywords:}

Anxiety; Childbirth;

Covid 19 Pandemic;

Pregnant Women

\begin{abstract}
ABSTRAK
Latar Belakang: Virus yang menyebabkan COVID-19 berasal dari golongan virus yang sama dengan virus penyebab severe acut respiratory syndrome (SARS) dan Middle- East respiratory syndrome (MERS). Ibu hamil dengan SARS dan MERS mengalami risiko lebih tinggi terhadap keguguran dan 3 kelahiran premature. Hal tersebut sangat dimungkinkan terjadi pada ibu hamil dengan COVID-19. Tujuan penelitian adalah Secara umum penelitian ini bertujuan untuk mengetahui bagaimana kecemasan ibu hamil menghadapi persalinan pada masa pandemi COVID-19 di wilayah kerja UPT Puskesmas Namo Terasi tahun 2020. Metode penelitian dalam penelitian ini adalah penelitian observasional analitik dengan pendekatan cross sectional. Adapun hasil penelitian ini adalah adanya hubungan bermakna antara status COVID$19(p=0,000)$, kepribadian $(p=0,000)$ dan stigma sosial $(p=0,000)$ dengan kecemasan pada ibu hamil menghadapi persalinan di UPT Puskesmas Namoterasi kecamatan Sei Bingai Kabupaten Langkat.

ABSTRACT
Background: The virus that causes COVID-19 is from the same virus
group as the virus that causes severe acute respiratory syndrome
(SARS) and Middle-East respiratory syndrome (MERS). Pregnant women
with SARS and MERS have a higher risk of miscarriage and premature
birth. This is very possible for pregnant women with COVID-19. In
general, this study aims to determine how anxious pregnant women face
childbirth during the COVID-19 pandemic in the UPT Namo Terasi Health
Center work area in 2020. The research method in this study was an
analytical observational study with a cross sectional approach. The
results of this study were that there was a significant relationship between
COVID-19 status ( $p=0.000)$, personality (p = 0.000) and social stigma ( $p$
$=0.000)$ with anxiety in pregnant women facing childbirth at the UPT
Puskesmas Namorasi, Sei Bingai sub-district, Langkat Regency.

ABSTRACT

group as the viru (SARS) and Middle-East respiratory syndrome (MERS). Pregnant women with SARS and MERS have a higher risk of miscarriage and premature birth. This is very possible for pregnant women with COVID-19. In general, this study aims to determine how anxious pregnant women face childbirth during the COVID-19 pandemic in the UPT Namo Terasi Health Center work area in 2020. The research method in this study was an analytical observational study with a cross sectional approach. The results of this study were that there was a significant relationship between $=0.000$ ) with anxiety in pregnant women facing childbirth at the UPT Puskesmas Namorasi, Sei Bingai sub-district, Langkat Regency.
\end{abstract}




\section{PENDAHULUAN}

Pada akhir tahun 2019, tepatnya 31 Desember 2019, Cina melaporkankasus pneumonia yang tidak diketahui penyebabnya. Awalnya kasus inidilaporkan di daerah Wuhan, Provinsi Hubei. Dalam tiga hari, pasien dengan kasus tersebut berjumlah 44 orang dan terus bertambah hingga saat iniberjumlah ribuan kasus. Coronavirus disease 2019 (COVID-19) adalahpenyakit yang sedang mewabah hampir di seluruh dunia saat ini, yangdisebabkan oleh virus Severe Acute Respiratory Syndrome Coronavirus2(SARS-CoV-2). Awalnya virus ini diberi nama novel Coronavirus (2019-nCoV)2kemudian pada tanggal 11 Februari 2020, World Health Organization (WHO) memberi nama virus baru tersebut Severe Acute RespiratorySyndromecoronavirus-2 (SARS-CoV-2) dan nama penyakitnya sebagaiCoronavirus disease 2019 (COVID-19).

Hingga tanggal 8 April 2020, data dari WHO didapatkan kasus terkonfirmasisebanyak 1.317.130 kasus tersebar di 212 negara dengan jumlah kematian 74.304 orang. Sementara data di Indonesia hingga tanggal 8 April 2020 menunjukkan kasus terkonfirmasi sebanyak 2.956 kasus tersebar di 32 provinsi dengan jumlah kematian 240 orang. Indonesia merupakan negara ke-65 yang positif konfirmasi COVID-19. Data ini menunjukkan Case Fatality Rate (CFR) di Indonesia sebesar 8,12\% lebih tinggi dari CFR secara global yaitu5,6\%.

Wabah Corona masih menjadi topik utama di seluruh dunia. Bahkan, sejakdi Indonesia ada yang dinyatakan positif terinfeksi Corona, masyarakat kian panik mencari informasi tentang Corona. Perubahan fisiologis pada sistem imun selama kehamilan dapat membuat ibu hamil lebih rentan terkena infeksi,termasuk infeksi virus Corona dan kelompok ibu hamil lebih berisiko mengalami gejala penyakit yang berat. Virus yang menyebabkan COVID-19 berasal dari golongan virus yang sama dengan virus penyebab severe acut respiratory syndrome (SARS) dan Middle- East respiratory syndrome (MERS). Ibu hamil dengan SARS dan MERS mengalami risiko lebih tinggi terhadap keguguran dan 3 kelahiran premature. Hal tersebut sangat dimungkinkan terjadi pada ibu hamil dengan COVID-19.

Menurut WHO, sejauh ini gejala yang akan dirasakan ibu hamil sama dengan yang lainnya. Dalam analisis 147 ibu hamil, hanya ada $8 \%$ yang memiliki gejala penyakit yang parah dan $1 \%$ dengan kondisi kritis. Ciri-ciri awal bila ibu hamil terpapar virus Corona, antara lain : demam (78\%), batuk (44\%), nyeri otot $(33 \%)$, rasa lemas menyeluruh $(22 \%)$, sesak nafas $(11 \%)$, dan sakit tenggorokan $(22 \%)$. Akan lebih dicurigai apabila ada ibu hamil dengan riwayat bepergian ke daerah yang terdampak dalam waktu 14 hari terakhir atau pernah kontak denganorang yang positif menderita COVID-19. Oleh sebab itu, harapannya ibu hamil tidak boleh panik, tetap tenang dan selalu waspada serta melakukan upaya pencegahan.

Coronavirus adalah suatu kelompok virus yang dapat menyebabkanpenyakit pada hewan dan manusia. Beberapa jenis coronavirus diketahui menyebabkan infeksi saluran pernapasan pada manusia mulai dari batuk pilek hingga yang lebih serius seperti Middle East Respiratory Syndrome (MERS) dan Severe Acute Respiratory Syndrome (SARS).Dari data COVID-19 Modelling Scenario terdapat perkiraan jumlah kasus yang terinfeksi yaitu 0,32\% untuk fatalisasi (kematian/terinfeksi), 0,36\% untuk perawatan kritikal (memerlukan perawataan ICU), 1,93\% untuk pneumonia, 11,4\% untuk kasus ringan, serta $86 \%$ 
untuk yang tidak terdeteksi/tidak menunjukan gejala namun menular.

Secara global total kasus konfirmasi COVID-19 global per tanggal 23 Juli 2020 adalah 15.012 .731 kasus dengan 619.150 kematian (CFR 4,1\%) di 215 Negara Terjangkit dan 171 Negara Transmisi lokal. Sementara di indonesia jumlah yang terkena COVID-19 Positif 95.418 Sembuh 53.945 Meningga 14.665. Sementara di sumatera utara Suspek 340 Konfirmasi 3320 Meninggal 173 Sembuh 873. 
Di indonesia saat ini mengalami penyebaran Virus COVID-19 yang membuat resah seluruh masyarakat.Banyaknya orang yang sudah terinfeksi COVID-19 tersebut menyebabkan ada kecemasan tersendiri pada pada sebagian kelompok masyarakat khususnya ibu hamil di wilayah kerja UPT Puskesmas Namo Terasi.Setelah terinfeksinya COVID-19 di indonesia menyebabkan banyak kerugian di indonesia. Mulai dari banyak kelompok masyarakat yang tidak dapat bekerja akibat kebijakan pemerintah yang mengharuskan masyarakat harus work from home bahkan dalam pendidikan saja harus dilakukan secara daring (dalam jaringan).

Dengan adanya kebijakan-kebijakan tersebut pasti ada kelebihan maupun kekurangan yang irasakan masyarakat. Pemerintah sudah mengeluarkan beberapa bantuan untuk membantu asyarakat agar tetap bisa menjalani hidup walaupun harus tetap berada didalam rumah. Update berita mengenai COVID-19 saat ini sudah sangat mudah di aksess di berbagai media, seperti media massa bahkan yang paling mudah di akses pada media sosial.

Kecemasan merupakan reaksi normal terhadap situasi yang sangat menekan kehidupan seseorang. kecemasan adalah suatu kejaian yang mudah terjadi pada sesorang karena suatu faktor tertentu tiak spesifik (sari \& batubara,2017). Kecemasan merupakan keadaan yang ana pola tingkah laku direpresentasikan ddengan keadaan emosional yang dihasilkan dari pikiran -pikiran dan perasaan yang tidak menyenangkan(purnamarini,setiawan \& hidayat,2016). Kartini kartono menjelaskan bahwa kecemasan adalah suatu bentuk ketakutan dan kerisauan dengan hal -hal tertentu tanpa kejelasan yang pasti.

Hal ini dikuatkan oleh sarlito wirawan bahwa kecemasan merupakan ketakutan yang tidak jelas pada suatu objek dan tidak memiliki suatu alasan tertentu (annisa \& ifdil, 2016). Kecemasan adalah reaksi yang dapat dialai oleh siapapun. Namun cemas yang berlebihan, apalagi yang suah enjadi ganguan akan menghambat fungsi seseorang dala kehidupannya. Demikian juga ibu hamil yang di wilayah kerja upt puskesas namo terasi. Kurangnya edukasi menyebabkan adanya kecemasan tersendiri pada ibu hamil. Ibu hamil tidak paham bagaimana penyebaran COVID-19 sehingga ibu hamil menjadi cemas dalam menghaapi persalinan pada masa pandemi ini.

Kecemasan pada ibu hamil dapat timbul pada trimester ketiga kehamilan sampai saat persalinan, dimasa pada periode ini ibu hamil merasa cemas terhadap berbagai hal seperti normal atau tidak normal bayinya lahir, nyeri yang akan dirasakan dan sebagainya.

Virus corona telah mengganggu rencana kehamilan dan meningkatkan kecemasan sebagian besar ibu hamil, yang mempertanyakan bagaimana dampak virus itu terhadap kelahiran bayi mereka. Dokter mengatakan, lebih banyak studi diperlukan untuk mengetahui dampak virus terhadap janin dan bayi. Namun yang terbaik untuk dilakukan ibu hamil saat ini adalah melakukan pembatasan sosial.

Kebanyakan ibu hamil merasa cemas jika melahirkan tanpa disertai orang- orang yang mereka kasihi di samping mereka.Sebagian lagi kuatir takut terinfeksi COVID-19 dan tidak dapat memeluk bayi mereka.Di wilayah kerja Upt Puskesmas Namoterasi, kabupaten langkat masih ada ibu hamil yang kurang edukasi mengalami kecemasan menghadapi persalinan akibat adanya COVID-19. Ibu hamil merasa dengan adanya kebijakan pemerintah yang ada mematikan mata pencaharian mereka. Kebijakan pemerintah memaksakan masyarakat untuk tetap berada dirumah 
tanpa keluar sama sekaali yang ada menyebabkan ibu hamil di wilayah kerja upt puskesmas namo terasi tidak bisa melakukn aktivitas. Dinamo terasi pada umumnya masyarakat bekerja dengan bercocok tanam secara tidaak llangsung harus melakukan aktivitas diluar rumah.Di wilayah kerja UPT Puskesmas Namoterasi sendiri masih belum merata dalam penyebaran informasi kepada masyarakat. Masyarakat apabila tidak mendapat edukasi dengan baik maka tidak akan paham apa maksud dan tujuan pemerintah dengan mengeluarkan kebijakan tersebut. Apabila adanya perbedaan persepsi antara masyarakat dengan pemerintah inilah yang terkadang menyebabkan masyarakat menjai tidak mau mengikuti peraturan yang dikeluarkan pemerintah. Kecemasan adalah sesuatu yang menimpa hampir setiap orang pada waktu tertentu dalam kehidupannya

\section{METODE PENELITIAN}

Penelitian ini merupakan penelitian observasional analitik dengan pendekatan cross sectional yaitu penelitian yang menggali, menganalisis Kecemasan Ibu Hamil dalam Menghadapi Persalinan pada masa pandemi COVID-19 di UPT Puskesmas Namoterasi kecamatan Sei Bingai Kabupaten Langkat. Data yang diperlukan diperoleh dari pembagian kuesioner kepada ibu hamil yang datang ke UPT Puskesmas Namoterasi.

\section{HASIL PENELITIAN}

\section{a. Analisis Univariat}

1. Distribusi Frekuensi Kecemasan pada Ibu Hamil Masa COVID-19

Tabel 1. Distribusi Frekuensi Kecemasan pada Ibu Hamil Masa COVID-19 di UPT Puskesmas Namoterasi kecamatan Sei Bingai Kabupaten Langkat

\begin{tabular}{ccc}
\hline Kecemasan Ibu Hamil Masa COVID-19 & Frekuensi (f) & Persentase (\%) \\
\hline Ringan & 80 & 76,2 \\
Sedang & 25 & 23,8 \\
\hline Jumlah & 105 & 100 \\
\hline
\end{tabular}

Berdasarkan tabel 1 dapat diketahui dari 105 orang ibu sebagian besar ibu hamil masa COVID-19 mengalami kecemasan ringan sebanyak 80 orang ibu $(76,2 \%)$.

2. Distribusi Status COVID-19

Tabel 2. Distribusi Frekuensi Status COVID-19 di UPT Puskesmas Namoterasi kecamatan Sei Bingai Kabupaten Langkat

\begin{tabular}{ccc}
\hline Status COVID-19 & Frekuensi (f) & Persentase (\%) \\
\hline Negatif COVID-19 & 90 & 85,7 \\
\hline Positif COVID-19 & 15 & 14,3 \\
\hline Jumlah & 105 & 100 \\
\hline
\end{tabular}

Berdasarkan tabel 2 dapat diketahui dari 105 orang ibu sebagian besar status COVID-19 negatif sebanyak 90 orang ibu $(85,7 \%)$.

3. Distribusi Kepribadian

Tabel 3. Distribusi Frekuensi Kepribadian di UPT Puskesmas Namoterasi kecamatan Sei Bingai Kabupaten Langkat

\begin{tabular}{ccc}
\hline Kepribadian & Frekuensi (f) & Persentase (\%) \\
\hline Ekstrovert & 83 & 79,0 \\
\hline Introvert & 22 & 21,0 \\
\hline Jumlah & 105 & 100
\end{tabular}


Berdasarkan tabel 3 dapat diketahui dari105 orang ibu sebagian besar memiliki kepribadian ekstrovert sebanyak 83 orang ibu $(79,0 \%)$.

4. Distribusi Stigma Sosial

Tabel 4. Distribusi Frekuensi Stigma Sosial di UPT Puskesmas Namoterasi kecamatan Sei Bingai Kabupaten Langkat

\begin{tabular}{ccc}
\hline Stigma Sosial & Frekuensi (f) & Persentase (\%) \\
\hline Rendah & 68 & 64,8 \\
\hline Tinggi & 37 & 35,2 \\
\hline Jumlah & 105 & 100
\end{tabular}

Berdasarkan tabel 4 dapat diketahui dari 105 orang ibu sebagian besar stigma sosial rendah sebanyak 68 orang ibu $(64,8 \%)$.

\section{b. Analisis Bivariat}

1. Hubungan antara Status COVID-19 dengan Kecemasan pada lbu Hamil di UPT Puskesmas Namoterasi kecamatan Sei Bingai Kabupaten Langkat

Tabel 5. Hubungan antara Status COVID-19 dengan Kecemasan pada Ibu Hamil di UPT Puskesmas Namoterasi kecamatan Sei Bingai Kabupaten Langkat Kecemasan pada Ibu Hamil

Status COVID-19

\begin{tabular}{cccccccr}
\multicolumn{2}{c}{ Ringan } & \multicolumn{2}{c}{ Sedang } & \multicolumn{2}{c}{ Jumlah } & & \\
\cline { 1 - 5 } $\mathrm{N}$ & $\%$ & $\mathrm{~N}$ & $\%$ & $\mathrm{~N}$ & $\%$ & Nilai $p$ & OR \\
\cline { 1 - 5 } 79 & 87,8 & 11 & 12,2 & 90 & 100 & & \\
1 & 6,7 & 14 & 93,3 & 15 & 100 & 0,000 & 100,545 \\
80 & 76,2 & 25 & 22,8 & 105 & 100 & & \\
\end{tabular}

Berdasarkan tabel 5 menunjukkan bahwa dari 90 orang ibu dengan status COVID-19 negatif terdapat 79 orang $(87,8 \%)$ mengalami kecemasan ringan, sedangkan dari 15 orang ibu dengan status COVID-19 positif terdapat 14 (93,3\%) mengalami kecemasan sedang. Hasil uji Chi-Square didapatkan nilai $p=0,000<0,05$ yang berarti ada hubungan yang bermakna antara status COVID-19 dengan kecemasan pada ibu hamil. Nilai OR sebesar 100,545, sehingga dapat dinyatakan bahwa ibu dengan status COVID-19 negatif berpeluang 100,545 kali mengalami kecemasan ringan dibandingkan ibu dengan status COVID-19 positif.

2. Hubungan antara Kepribadian dengan Kecemasan pada Ibu Hamil di UPT Puskesmas Namoterasi kecamatan Sei Bingai Kabupaten Langkat

Tabel 6. Hubungan antara Kepribadian dengan Kecemasan pada Ibu Hamil di UPT Puskesmas Namoterasi kecamatan Sei Bingai Kabupaten Langkat

\section{Kecemasan padalbuHami}

\begin{tabular}{|c|c|c|c|c|c|c|c|c|}
\hline \multirow{2}{*}{ Kepribadian } & \multicolumn{2}{|c|}{ Ringan } & \multicolumn{2}{|c|}{ Sedang } & \multicolumn{2}{|c|}{ Jumlah } & \multirow{2}{*}{ Nilai $p$} & \multirow{2}{*}{ OR } \\
\hline & $\mathrm{N}$ & $\%$ & $\mathrm{~N}$ & $\%$ & $\mathrm{~N}$ & $\%$ & & \\
\hline Ekstrovert & 77 & 92,8 & 6 & 7,2 & 83 & 100 & & \\
\hline Introvert & 3 & 13,6 & 19 & 86,4 & 21 & 100 & 0,000 & 81,278 \\
\hline Total & 80 & 76,2 & 25 & 22,8 & 105 & 100 & & \\
\hline
\end{tabular}

Berdasarkan tabel 6 menunjukkan bahwa dari 83 orang ibu dengan kepribadian ekstrovert terdapat 77 (92,8\%) mengalami kecemasan ringan, sedangkan dari 21 orang 
ibu dengan kepribadian introvert terdapat $19(86,4 \%)$ mengalami kecemasan sedang. Hasil uji Chi-Square didapatkan nilai $p=0,000<0,05$ yang berarti ada hubungan yang bermakna antara kepribadian dengan kecemasan pada ibu hamil. Nilai OR sebesar 81,278, sehingga dapat dinyatakan bahwa ibu dengan kepribadian ekstrovert berpeluang 81,278 kali mengalami kecemasan ringan dibandingkan ibu dengan kepribadian introvert.

3. Hubungan antara Stigma Sosial dengan Kecemasan pada Ibu Hamil di UPT Puskesmas Namoterasi kecamatan Sei Bingai Kabupaten Langkat

Tabel 7. Hubungan antara Stigma Sosial dengan Kecemasan pada Ibu Hamil di UPT Puskesmas Namoterasi kecamatan Sei Bingai Kabupaten Langkat

\begin{tabular}{|c|c|c|c|c|c|c|c|c|}
\hline \multirow{3}{*}{ Stigma Sosial } & \multicolumn{4}{|c|}{ Kecemasan padalbuHami } & & & \multirow{3}{*}{ Nilai $p$} & \multirow{3}{*}{ OR } \\
\hline & \multicolumn{2}{|c|}{ Ringan } & \multicolumn{2}{|c|}{ Sedang } & \multicolumn{2}{|c|}{ Jumlah } & & \\
\hline & $\mathrm{N}$ & $\%$ & $\mathrm{~N}$ & $\%$ & $\mathrm{~N}$ & $\%$ & & \\
\hline Rendah & 63 & 92,6 & 5 & 7,4 & 68 & 100 & & \\
\hline Tinggi & 17 & 45,9 & 20 & 54,1 & 37 & 100 & 0,000 & 14,824 \\
\hline Total & 80 & 76,2 & 25 & 22,8 & 105 & 100 & & \\
\hline
\end{tabular}

Berdasarkan tabel 7 menunjukkan bahwa dari 68 orang ibu dengan stigma sosial rendah terdapat 63 orang $(92,6 \%)$ mengalami kecemasan ringan, sedangkan dari 37 orang ibu dengan stigma sosial tinggi terdapat $20(54,1 \%)$ mengalami kecemasan sedang. Hasil uji Chi-Square didapatkan nilai $p=0,000<0,05$ yang berarti ada hubungan yang bermakna antara stigma sosial dengan kecemasan pada ibu hamil. Nilai OR sebesar 14,824, sehingga dapat dinyatakan bahwa ibu dengan stigma sosial rendah berpeluang 14,824 kali mengalami kecemasan ringan dibandingkan ibu dengan stigma sosial tinggi.

\section{PEMBAHASAN}

\section{1) Sebelum diberikan Asuhan Yoga Postnatal}

Pada masa postpartum ibu mengalami proses adaptasi untuk membantu tubuh memulihkan diri setelah persalinan. Proses adaptasi pada ibu postpartum dibagi menjadi dua, yaitu adaptasi fisiologis dan adaptasi psikologis. Adaptasi fisiologis meliputi proses kembalinya kondisi fisik dan sistem organ tubuh ibu seperti sebelum hamil, sedangkan adaptasi psikologis meliputi perubahan emosional dan kesehatan mental (Ni Wayan, 2018), oleh karena itu ibu postpartum mengalami penurunan dari segi fisik, psikologis, dan social dari kondisi sebelumnya karena peran barunya. Tanggung jawab untuk melakukan perannya sebagai ibu baru, perawatan bayi dan keluarganya serta proses pemulihan pasca persalinan membuat ibu cukup rentan mengalami resiko infeksi, penurunan daya tahan tubuh, perubahan mood atau perubahan perilaku yang terkait dengan kondisi tubuh dan psikologinya (dewi, 2018)

Berdasarkan hasil penelitian menunjukan bahwa kondisi psikologis ibu sebelum dilakukan yoga postnatal pada ibu postpartum di klinik kebidanan Afifah dengan jumlah 24 responden hampir dari setengah ibu postpartum mengalami gangguan psikologis dengan skala 2 (depresi sedang) dengan jumlah 17 responden (70,8\%).Menurut penelitian Lastri Mei Winami, dkk kondisi psikologis ibu sebelum dilakukan tindakan yoga postnatal pada ibu nifas dengan jumlah 54 responden, hampir dari setengah ibu mengalami gangguan Psikologis (96\%).Kondisi Psikologis yang dialami tersebut dapat di berikan asuhan yoga postnatal yang merupakan bagian dari terapi non farmakologis yang 
merupakan upaya praktis dalam menyelaraskan tubuh, pikiran, dan jiwa, yang mana manfaat yoga membentuk postur tubuh yang tegap, serta membina otot yang lentur dan kuat, memurnikan saraf pusat yang terdapat di tulang punggung.

\section{2) Setelah diberikan asuhan yoga postnatal}

Berdasarkan hasil kondisi psikologis dengan skala Edinburgh Pospartum Depression Scala (EPDS), setelah diberikan perlakuan yoga postnatal dari 24 responden terdapat 21 responden (87.5\%) yang skala depresinya berkurang menjadi tidak ada tanda resiko depresi. 3 responden dengan resiko depresi sedang (12.5\%), dan tidak terdapat resiko depresi berat $(0.0 \%)$. Menurut Bridges \& Sharma (2017), Melissa Mercedes Buttner (2013), Y.-L. Ko, Lin, Yang, Chen, \& Shih, (2015) berdasarkan pengalaman pribadi, yoga dapat membantu menurunkan tingkat stress dan emosi. Kamei dkk dalam penelitiannya menjelaskan bahwa setelah yoga, diketahui serum kortisol dalam darah akan menurun dan mengubah gelombang otak menjadi gelombang alpha ( $\alpha$ ). Gelombang alpha merupakan gelombang di otak yang berada pada frekuensi 8-13 Hz. Biasanya gelombang ini muncul pada saat manusia beristirahat dengan memejamkan mata, diawal menjelang tidur (Winarmi, 2020) Latihan yoga secara teratur dapat mengurangi rasa nyeri secara fisik, menguatkan otot-otot tubuh, menurunkan stress, emosi, kecemasan serta membantu proses penyembuhan dari sakit (Winarmi, 2020).

\section{Hubungan antara Status COVID-19 dengan Kecemasan pada lbu Hamil di UPT Puskesmas Namoterasi kecamatan Sei Bingai Kabupaten Langkat}

Hasil analisis bivariat ditemukan bahwa ada dari 90 orang ibu dengan status COVID-19 negatif terdapat 79 orang $(87,8 \%)$ mengalami kecemasan ringan, sedangkan dari 15 orang ibu dengan status COVID-19 positif terdapat 14 orang $(93,3 \%)$ mengalami kecemasan sedang. Hasil uji Chi-Square didapatkan nilai $p=0,000<0,05$ yang berarti ada hubungan yang bermakna antara status COVID-19 dengan kecemasan pada ibu hamil. Nilai OR sebesar 100,545, sehingga dapat dinyatakan bahwa ibu dengan status COVID-19 negatif berpeluang 100,545 kali mengalami kecemasan ringan dibandingkan ibu dengan status COVID-19 positif.

Bender et al (2020) menjelaskan bahwa wanita yang dalam masa kehamilan merupakan kelompok yang rentan mengalami gangguan psikologi, termasuk gangguan kecemasan. Adanya pandemi seperti ini dapat menjadi faktor risiko yang memengaruhi terjadinya peningkatan kecemasan pada wanita hamil. Corbett et al (2020) menyatakan pendapat bahwa adanya instruksi atau kebijakan pemerintah tentang menjaga jarak dan kontak fisik, serta media massa yang menjadi lebih sering menginformasikan tentang COVID-19 juga berperan terhadap perubahan besar pada perilaku wanita hamil sehingga merasa berada di bawah tekanan dapat menyebabkan efek buruk secara tidak langsung kesehatan fisik dan kesehatan psikologis.Peneliti berasumsi adanya hubungan status COVID-19 dengan kecemasan pada ibu hamil, hal ini disebabkan oleh karena adanya kekhawatiran terhadap bayi yang dikandungnya, di samping itu adanya perasaan gangguan psikologis karena merasa terasingkan. Hal ini dapat dilihat dari hasil penelitian didapatkan ibu dengan status COVID-19 positif didapatkan sebagian besar mengalami kecemasan sedang yang 
disebabkan oleh karena adanya kekhawatiran jika adanya kelainan pada bayinya, disamping itu ibu mengalami adanya kecemasan jika masyarakat tidak menerima kondisi dirinya karena takut apabila berdekatan akan terkena virus COVID-19 tersebut.

\section{Hubungan antara Kepribadian dengan Kecemasan pada Ibu Hamil di UPT Puskesmas Namoterasi kecamatan Sei Bingai Kabupaten Langkat}

Berdasarkan hasil analisis bivariat ditemukan bahwa dari 83 orang ibu dengan kepribadian ekstrovert terdapat 77 orang $(92,8 \%)$ mengalami kecemasan ringan, sedangkandari 21 ibu dengan kepribadian introvert terdapat $19(86,4 \%)$ mengalami kecemasan sedang. Hasil uji Chi-Square didapatkan nilai $p=0,000<0,05$ yang berarti ada hubungan yang bermakna antara kepribadian dengan kecemasan pada ibu hamil. Nilai OR sebesar 81,278 , sehingga dapat dinyatakan bahwa ibu dengan kepribadian ekstrovert berpeluang 81,278 kali mengalami kecemasan ringan dibandingkan ibu dengan kepribadian introvert.

Maramis (2015) menjelaskan cara seseorang dalam menyelesaikan konflikdan menyesuaikan dirinya tergantung pada emosi, intelegensi, dan kepribadiannya. Setiap kepribadian akan menunjukkan bagaimana seseorang itu akan bersikap terhadap semua keadaan mengancam yang diterimanya. Menurut psikolog Jung dalam Sunaryo (2017) )orang dengan kepribadian ekstrovert interaksinya dengan dunia luar sangat baik. Mereka adalah orang-orang yang ramah, mudah bergaul,suka mengunjungi tempat baru, berperilaku aktif, mudah bosan dan tidak menyukai aktivitas yang rutin dan monoton. Tindakannya banyak dipengaruhi oleh dunia luar,dan bersifat terbuka. Semnetara menurut Feist \& Feist (2016) seseorang dengan tipe kepribadian introvert cenderung tertutup dan sangat menghargai privasi. Introvert tidak suka menceritakan perasaannya atau hal pribadi kesembarangan orang, sehingga mereka cenderung menutupi apa yang sebenarnya mereka rasakan.

Peneliti berasumsi adanya hubungan antara tipe kepribadian dengan kecemasan pada ibu hamil, hal ini disebabkan oleh karena ibu dengan tipe kepribadian ekstrovert akan terbuka terhadap orang lain sehingga ketika ditemukan adanya masalah ibu dapat mengetahui solusinya. Hal ini menjadikan kecemasan yang dialami ibu berkurang. Berbeda dengan ibu yang memiliki tipe kepribadian introvert dimana Ibu bersikap tertutup terhadap orang lain sehingga ketika ditemukan adanya masalah Ibu tidak dapat menemukan solusinya. Kondisi inilah yang menimbulkan ibu mengalami kecemasan sedang. Perlu kiranya untuk mengurangi kecemasan khususnya pada ibu dengan tipe kepribadian introvert yaitu dengan melakukan hubungan lebih dekat antara tenaga kesehatan dengan Ibu hamil agar dapat diketahui solusinya untuk memecahkan masalah yang dihadapi oleh ibu hamil tersebut.

\section{Hubungan antara Stigma Sosial dengan Kecemasan pada Ibu Hamil di UPT Puskesmas Namoterasi kecamatan Sei Bingai Kabupaten Langkat}

Berdasarkan hasil analisis bivariat ditemukan bahwa dari 68 orang ibu dengan stigma sosial rendah terdapat $63(92,6 \%)$ mengalami kecemasan ringan, sedangkan dari 37 orang ibu dengan 
stigma sosial tinggi terdapat $20(54,1 \%)$ mengalami kecemasan sedang. Hasil uji Chi-Square didapatkan nilai $p=0,000<0,05 y$ yng berarti ada hubungan yang bermakna antara stigma sosial dengan kecemasan pada ibu hamil. Nilai OR sebesar 14,824, sehingga dapat dinyatakan bahwa ibu dengan stigma sosial rendah berpeluang 14,824 kali mengalami kecemasan ringan dibandingkan ibu dengan stigma sosial tinggi.

Liu, et al (2020) mengatakan bahwa reaksi masyarakat terhadap penyebaran COVID-19 dapat berupa proteksi secara berlebihan terhadap diri sendiri maupun keluarganya. Kondisi tersebut dapat menimbulkan gejala obsesif compulsif yaitu gangguan mental yang menyebabkan penderita merasa harus melakukan suatu tindakan secara berulang-ulang. Bila tidak dilakukan, individu tersebut akan terus diliputi kecemasan atau ketakutan. Kang, etal (2020) menambahkan bahwa kecemasan dan ketakutan berdampak pada tindakan menjauhi setiap individu yang berpotensi menjadi sumber penularan, sehingga timbul diskriminasi dan terjadilah stigma negatif pada masyarakat yang kontak erat dengan kasus COVID-19. Penyebab stigma negatif tersebut diakibatkan kurangnya pengetahuan dan informasi, kecemasan, mekanisme koping dan support system yang ada pada masyarakat.

Peneliti berasumsi adanya hubungan antara stigma dengan kecemasan pada ibu hamil, hal ini disebabkan oleh karena adanya ketakutan terjadinya penularan terhadap penyakit tersebut. Ibu dengan stigma yang tinggi mengalami kecemasan, hal ini disebabkan oleh adanya ketakutan Ibu tersebut dikucilkan. Ibu mengalami kekhawatiran jika orang lain tersebut tidak mau berdekatan dengannya sehingga mengalami kecemasan. Berbeda dengan ibu yang memiliki stigma rendah mengalami kecemasan ringan disebabkan oleh karena ibu tidak mengalami kekhawatiran dan tidak merasakan ketakutan bahwa dia akan dikucilkan.

\section{SIMPULAN DAN SARAN}

\section{SIMPULAN}

Berdasarkan hasil dan pembahasan dalam penelitian dapat disimpulkan bahwa Dari 105 orang ibu sebagian besar ibu hamil masa COVID-19 mengalami kecemasan ringan sebesar $76,2 \%$, sebesar $85,7 \%$ berstatus COVID-19 negatif, status ekonomi $\geq$ UMK sebesar 60,0\%, kepribadian ekstrovert sebesar $79,0 \%$, dan stigma sosial rendah sebesar $64,8 \%$. Terdapat adanya hubungan bermakna antara status COVID-19 $(p=0,000)$, status ekonomi $(p=0,000)$, kepribadian $(p=0,000)$ dan stigma sosial $(p=0,000)$ dengan kecemasan pada ibu hamil di UPT Puskesmas Namoterasi kecamatan Sei Bingai Kabupaten Langkat

\section{SARAN}

Diharapkan kepada peneliti selanjutnya agar dapat mengembangkan atau melakukan penelitian dengan variabel, skala penelitian dan tempat penelitian yang berbeda yaitu tentang kecemasan pada ibu hamil.Disarankan kepada Puskesmas agar dapat memberikan dukungan khususnya kepada ibu dengan status COVID-19 positif dengan pemberian informasi dan pemeriksaan kesehatan. Diharapkan kepada lbu agar dapat melakukan upaya pencegahan terjadinya COVID-19 dengan 5M yaitu gunakan masker saat berhubungan dengan orang lain atau 
pergi keluar rumah, rajin mencuci tangan sebelum dan sesudah melakukan tindakan, lakukan jaga jarak minimal 1 meter dengan orang lain, jauhi kerumunan dan kurangi aktivitas diluar.

\section{DAFTAR PUSTAKA}

Arief, N. (2016). Kehamilan dan Kelahiran Sehat. Yogyakarta:Dianloka.

Asy'ari, R. (2020). Makalah Bahasa Indonesia Pengertian COVID-19 dan Bentuk Partisipasi dalam Memeranginya. Universitas Negeri Surabaya.

Astuti, M. (2015). Buku Pintar Kehamilan. Jakarta: EGC.

Chaplin,J.P. (2015). Kamus Lengkap Psikologi. Alih Bahasa: Kartono Kartini, Jakarta: Raja Grafindo.

Chairani, M. (2016). Hubungan Tipe Kepribadian dengan Tingkat Kecemasan pada Mahasiswa Program Studi Pendidikan Dokter Fakultas Kedokteran Universitas Syiah Kuala. Skripsi. Universitas Syiah Kuala Banda Aceh

Daradjat, Z. (2016). Kesehatan Mental. Jakarta: PT Gunung Agung. Firdaus, I. (2014) Dampak Hebat Emosi Kesehatan. Jogjakarta: Flah Book.Gerungan, W.A. (2014). Psikologi Sosial. Bandung: Eresco.

Huizink. (2016). Adaption of Pregnancy Anxiety Questionnaire-Revised for All Pregnant Women Regardless of Parity: PRAQ-R2. Arch Womens Ment Health DOI.

Hurlock, E, B. (2017). Psikologi Perkembangan Suatu Pendekatan Rentang Kehidupan. Jakarta: Erlangga.

ILEP. (2015). Guidelines to Reduce Stigma Guide 2 How to Assess Health- Related Stigma. London: The International Federation of Anti-Leprosy Associations (ILEP) and the Netherland Leprosy Relief (NLR).

Janiwarty, B dan Pieter, H. Z. (2015). Pendidikan Psikologi untuk Bidan Suatu Teori dan Terapannya, Yogyakarta: Rapha Publishing.

Maimunah, S. (2015). Kamus Istilah Kebidanan. Jakarta : EGC.

Maramis, W.F. (2015). Catatan Ilmu Kedokteran Jiwa. Surabaya: AirlanggaUniversity press.

Novianti S. (2015). Korelasi Tingkat Kecemasan Maternal dan Kejadian BBLR.Jurnal Kesehatan Komunitas Indonesia Vol. 11. No. 2. Universitas Siliwangi Tasikmalaya.

Poon, L. C. et al. (2020). Global Interim Guidance on Corona virus Disease 2019 (COVID-19) During Pregnancy and Puerperium from FIGO and Allied Partners: Information for Healthcare Professionals. International Journal of Gynecology and Obstetrics,149(3), pp. 273-286. doi:10.1002/ijgo.13156.

Rahmita, N. (2017). Tingkat Kecemasan pada Ibu Hamil Primigravida Trimester Ketiga di Puskesmas Kecamatan Tamalanrea Makassar. Skripsi. Universitas Hasanuddin.

Ritonga. (2017). Pengetahuan Sosial Ekonomi. Jakarta: Erlangga.

Said, N., Kanine, E., Bidjuni, H. (2015). Hubungan Faktor Sosial Ekonomi dengan Kecemasan Ibu Primigravida di Puskesmas Tuminting. ejournal Keperawatan (e-Kp). Volume 3. Nomor2. Hal 18.

Stuart dan Sundeen. (2017). Buku Saku Keperawatan Jiwa. Jakarta: EGC. 
Suherlan, H., Budhiono, Y. (2015). Psikologi Pelayanan. Bandung: Media Perubahan.

Usman FR, Kundre RM, Onibala F. (2016). Perbedaan Tingkat Kecemasan Ibu Hamil Menghadapi Persalinan Dengan Kepatuhan Antenatal Care (ANC) Di Puskesmas Bahu Kota Manado. Ejournal Keperawatan (e-Kp). Volume 4 Nomor 1, Hal 1-7.

Vellyana, D., Lestari, A., Rahmawati, A. (2017). Faktor-Faktor yang Berhubungan dengan Tingkat Kecemasan pada Pasien Preoperative di RS Mitra Husada Pringsewu. Jurnal Kesehatan, Volume VIII, Nomor 1, hIm 108-113.

Yusuf S dan Nurihsan J.(2017). Teori Kepribadian. Bandung: PT. Remaja Rosdakarya. 